RESEARCH NOTES

\title{
The Influence of Internet - Communication on Everyday Speech
}

\section{La influencia de Internet: la comunicación en el habla cotidiana}

\author{
Liana Ildarovna Galiullina \\ Kazan Federal University Kazan, Russia \\ ORCID ID: https://orcid.org/0000-0002-4945-6995 \\ Eleanor Wright \\ Kazan Federal University Kazan, Russia \\ ORCID ID: https://orcid.org/0000-0001-5134-7985
}

Received 09-08-20 Revised 10-10-20

Accepted 20-12-21 On line 02-16-21

\section{Correspondence}

Email: lianagaliullina3@gmail.com
Citation:

Liana Ildarovna Galiullina, and Eleanor Wright. (2021). The Influence of Internet - Communication on Everyday Speech. Propósitos y Representaciones, 9(SPE2), e1002. doi: http://dx.doi.org/10.20511/pyr2021.v9nSPE2.1002 


\section{Summary}

The article deals with the problem of the reverse influence of the Internet and chat communication on the spoken language based on the "Language of scum" in the Russian-speaking Internet. Today, this problem is relevant, since the development of the Internet has contributed to the widespread use of slang among the younger generation. The Internet today is a source of information. But the speed and availability of communication between users made it possible to use the Internet not only as a cognitive tool, but also as a means of communication and entertainment. And virtual communication, which arose due to the rapid development of the network, gave rise to a special language - the language of virtual communication. The numerous chats, open forums and personal pages created on the network are the main ways of communication among young people. Over the years, a special language has developed in the programs - slang, the so-called language of Internet communication, in which users communicate with each other. And every day he actively penetrates into our daily life. This study is a kind of appeal not only for adolescents, but also for the adult population. I would like people to think about the fact that we need to protect our language and not succumb to the influence of slang when communicating on social networks. The practical significance of the work lies in the fact that the results of this study will be useful to students in order to preserve their native language.

Keywords: ecolinguistics, Internet - communication, slang, slang words, meme, memorial culture, errativ.

\section{Resumen}

El artículo examina el problema de la influencia inversa de Internet y la comunicación por chat en el idioma hablado basado en el "Idioma de la escoria" en Internet de habla rusa. Hoy en día, este problema es relevante, ya que el desarrollo de Internet contribuyó al uso generalizado de la jerga entre la generación más joven. Internet hoy es una fuente de información. Pero la rapidez y la disponibilidad de la comunicación entre los usuarios hizo posible utilizar Internet no solo como una herramienta cognitiva, sino también como un medio de comunicación y entretenimiento. Y la comunicación virtual, que surgió debido al rápido desarrollo de la red, dio lugar a un lenguaje especial: el lenguaje de la comunicación virtual. Los numerosos chats, foros abiertos y páginas personales creadas en la red son las principales vías de comunicación entre los jóvenes. A lo largo de los años, se ha desarrollado un lenguaje especial en los programas: la jerga, el llamado lenguaje de la comunicación por Internet, en el que los usuarios se comunican entre sí. Y todos los días penetra activamente en nuestra vida diaria. Este estudio es una especie de atractivo no solo para los adolescentes, sino también para la población adulta. Me gustaría que la gente pensara en el hecho de que debemos proteger nuestro idioma y no sucumbir a la influencia de la jerga cuando nos comunicamos en las redes sociales. La importancia práctica del trabajo radica en el hecho de que los resultados de este estudio serán de utilidad para los estudiantes con el fin de preservar su lengua materna.

Palabras clave: ecolingüística, Internet - comunicación, jerga, jerga, meme, cultura conmemorativa.

\section{Introduction}

The paper deals with the problem of Internet language on people's speech. In the era of technology speech is constantly changing and adjusting. The incipience of the Internet has become an important impetus to the modernization of the language. It has seriously affected the communication of people. Social networks caused a new style of communication, a new etiquette. This may well be a valid point. Perhaps we are slowly plunging towards an easy and lazy way of 
exchanging information with each other. Perhaps in 15 years time our children will try to read classic masterpiece novels wearing expressions of bewilderment and confusion. The common theme, however, often seems to be that older people, as with many other new technologies, take a very negative view on new developments (Sibthorpe, 2014). During busy life, oral communication with a person is perceived as a kind of load on him. In this regard, the language strives for simplicity and conciseness, so in this case minimum of effort is spent on the conversation. In studying language and technology, we look at how the technology influences the language use, but we should not assume that the use of technology to meditate the language necessarily changes everything (Kovalenko, 2010). Communication via messages is quite convenient because the answer can be given at any time. However it is not always rational. The solution of a question is delayed for a long time, people send each other dozens of messages, although it would be possible to deal with the problem in one conversation.

Communication on the Internet forced people to stop using such a punctuation mark as "dot". This punctuation mark is often replaced by a smiley face. If the text consists of several sentences, a dot is placed between them, but it is ignored at the end of the message. Today, emoticons only inform about the emotional attitude of the author to the text. "Emoji is an anglicised version of two Japanese words - e "picture" and "moji"- character" (Evans, 2017). They convey the direction and degree of his emotions (and the type of emoticon does not matter). As we see, the emotional palette is very poor.

Nowadays there is a tendency to replace capacious Russian words with various foreign words. It is popular mostly among young generation. The use of such words in speech is considered fashionable and modern. There are many examples of such words: battle, single, boyfriend, shopping, etc. A huge number of slang (jargon) words and expressions have their origin in a foreign language. One of the most popular examples is LOL, an acronym for the English expression "Laughing out loud," to laugh out loud. Such slang words are especially popular on social networks, but the same way of communication is transferred to live communication (https://www.amazon.com).

Slang developed by Internet users is becoming very common, the revival of the epistolary genre in the form of electronic correspondence also has own language specifics. Modern industrialized societies are dynamic, rapidly changing, and therefore the language, or rather its verbal shell in such societies is very mobile, as a result of which the vocabulary undergoes major changes during the life of one generation (Golovanova, 2012). The specificity of communication on the Internet contributes to illiterate and thoughtless writing, as it assumes the anonymity of the user. This fact gives greater freedom of expression and action, because the risk of exposure and negative personal assessment of others is minimal. As a result of this, a feature manifests itself in the network that is associated with a decrease in psychological and social risk in the communication process - affective emancipation, profanity and some irresponsibility of the participants in communication.

The manner of communication and competent writing depend on the form of virtual communication (forums, guest books, chats, conferences, e-mails, blogs, personal diaries). New phenomena of our life, changing under the dash of modern technology, everyday habits require new words (Levikova, 2004).

Each of these forms has its own unique tradition of communication and makes special demands on the language in which communication takes place. For example, forums are a place network communication of a group of authors, where the notes are united by a common theme. The remarks of the forum participants are more consistent with the manner of writing: the statements are logically structured, completed and informative. The forums are struggling with unpleasant slang and obscene language.

\section{Methods}


1. Theoretical analysis of literature and Internet sources;

2. Practical analysis of information in social networks;

3. Social survey, questionnaire;

4. Classification of errors;

5.Analysis of the causes of errors;

6. Collection and analysis of information.

In order to analyze the impact of Internet communication on the literacy of adolescents, we examined the sites, blogs, forums, chats most often visited by my classmates, and made the following conclusions.

The specificity of communication on the Internet contributes to illiterate and thoughtless writing. Over the past few years blogs have become are very popular. It is an online diary of one or more authors. They are in complete disarray. This is an exclusively youthful way of communication and expression yourself. Users do not bother with detailed comments, preferring common phrases from network jargon: "Я плакалЪ", "Пеши исчо". With the help of such distortion of the language (deviation from the norms of Russian literature, active literature, active punctuation, using capital letters inside words), young people convey their emotions: irony, sarcasm, surprise, resentment. The owner of the personal diary looks at the order, as a rule, correspondence is carried out using slang.

Russian language of virtual communication is under the influence of the American version of the English language, which dictates its rules for communicating on the network. One of the most obvious borrowings by the Russian-speaking user of the English-speaking is the use of generally accepted emoticons ("emoticons").

The main purpose of using such system is to save time allotted for communication. Lack of time is a sign of modern society as a whole: the pace of life is accelerating every day, and the language, accordingly, is adapting to new conditions of functioning

Harald Haarman identifies 7 environmental variables that determine linguistic behavior: demographic, social, political, cultural, mental, interactive, linguistic (But, 2011). All of them are interconnected and cannot be separated. Thus, most of the phenomena of the accelerated development of languages in world history can be correlated with specific factors (the great migration of peoples, the formation of an "American accent" in English, the emergence of slang African-Americans in pop culture and its penetration into the general oral in America of the 20th century, the emergence of a huge amount abbreviations and semantic word formation at the beginning of the 20th century in Russia, the emergence of new local phenomena in bilingual regions (Ayda instead of come on) and others). V.G. Kostomarov writes about the unification of the two "style kingdoms" into a special "intermediate kingdom" that destroys the "great wall of China between oral and written texts, then we can talk about the inverse effect of the Internet language on oral colloquial speech, in which the examples of errativa "bastards" are heard.

However, the problem of integrating the Internet language into spoken language does not end with a threat of literacy or language degradation. Recently, "memes" (units of information significant to a culture) have gained popularity on the web. A meme is any idea, symbol, manner or mode of action, consciously or unconsciously, transmitted from person to person through speech, writing, video, rituals, gestures. And they already do not just force them to repeat the formed speech formulas that describe, for example, life situations or reactions to information, but create a "meme" way of thinking, which, in our opinion, already affects not only the environmental problems of the language, but also cognitive linguistics and psycholinguistics. The notion of meme as discourse is central to political internet memes, as evidenced in work by Milner, who examined internet memes as a method of understanding discourse and identity in a participatory media culture (Haarmn, 1986). Memes serve many purposes and functions, but at a fundamental level, they serve as an expression of people's opinions and emotions. Memes can be formed by appropriating scenes or lines from TV shows and movies, which are then taken out of context, remixed with other content and have new meanings attributed to them in a funny and relatable manner. Meme content can range from complaining about the hardships of being a 
college student, to expressing embarrassment felt during an encounter in a person's daily life something that everyone is able to sympathise with.

The rise of memes in our everyday online vocabulary has had people asking how they affect one's ability to communicate. On one hand, memes (made up of very concise messages in a short text or image format) are widely understood by a lot of people across the world regardless of their native language, and they help to foster strong relationships within the cyber community. On the other hand, there are people in certain circles who believe that memes, having become many a teen's vernacular language, have had the opposite effect. Memes are, they would argue, hindering communication in more ways than stripping everything down to one-liners and pictures. They can be used to aggravate hostile and prejudicial attitudes against certain races, against a particular gender, a religion, or a sexuality, thus widening the schism between people rather than bridging them.

Methods of constructing and disseminating memes, their dynamics are covered in philological works, for example, articles by E. V. Savitskaya and Yu. V. Schurina (Collins, 2017). However, most studies are theoretical, and the Internet meme itself becomes their object. Nevertheless, Internet memes became popular in the early 2010s and are distributed mainly on social networks among young people (18-34 years old) who are the most active users of social networks, at least in the Russian-speaking Internet space.

The term "meme" was first used by Richard Dawkins (Savitskaya, 2013). His definition was the first and gave rise to an approach to the study of memes as replicators of cultural information. This approach can be called reductionist, since it reduces the explanation of a complex phenomenon to the simplest units that interact with each other. It is used, inter alia, by well-known cognitive scientists, such as Douglas Hofstadter and Daniel Dennett. It is memes in the broad sense, based on biological analogies, that are the subject of many popular science books, for example, "Mental viruses.

To find out the attitude of adolescents to this problem, we conducted a survey of network users - the Internet.

Students were asked questions.

\section{Results and Discussion}

- Students communicate more in life than on social networks - $79 \%$ of $100 \%$.

- $65 \%$ of the respondents try to adhere to the norms of the Russian language when communicating on social networks, but they use emoticons - 90\%, graphic abbreviations or replacement of words - 83\%. Thus, we can conclude that modern adolescents express their thoughts quickly and emotionally, not paying attention to literacy.

$-22 \%$ can not refuse the use of smiles and all kinds of abbreviations

$-55 \%$ of respondents to the question "Do you think that a change in the spelling of words on the Internet affects your practical literacy? Most of the students who answered "no" to this question wrote in the questionnaire that they did not use slang, they applied the rules when writing texts, the rules of spelling and punctuation, the words, if they were shortened, then by the rules, observing the norms of the Russian language. However, the words do not distort, but emoticons are used when writing. ("When I write, I apply the rules. If you write incorrectly, you will get used to it and you will always write like that"; "I change words, use slang, but I read books, and my literacy does not deteriorate).

The students who answered "yes" to this question explained their answer as follows:

"No. Because as I wrote, I am writing with errors"; "I get used to writing incorrectly, and then I write in notes, notebooks"; "I memorize interesting abbreviations and cool buzzwords, and of course, because of this I start to write illiterate"; 
"It affects because we communicate more on the Internet than we write in the Russian language lesson, so we get used to writing with mistakes, we write in everyday life"; "Yes, because not all sites emphasize errors, and I don't know if I write with errors or not ".

\section{RESULTS}

The results of a sociological survey of students give us the opportunity to think that while communicating on social networks, spelling rules are not used by all students, but most of the respondents try to comply with them. Students prefer a smile or a graphic designation to the expression of thought, which makes their speech sparing. Before, when there was no Internet and satellite television, people read books. Accordingly, they developed visual memory, and they wrote correctly. Now there is a clear illiteracy among students who do not read books and use a lot of slang words in their speech.

In conclusion, Internet communication contributes to the development of illiteracy among the younger generation.

Another superstitious of the XXI century is the lack of time which has an immediate impact on our communication. I began to notice that the guys started to communicate much faster, using a lot of abbreviations in their speech in order to save time. For instance, instead of saying the word “норм» or «намана», instead of «пойдем» - «падем», «спасибо» - «спс», «почему» «поч», «может быть» - «мб», «домашнее задание» - «дз etc.. Young people often use English words in conversation. For instance, many teenagers, greeting, began to use the English word "Hi" instead of the word "Привет".

Thus, Internet slang is actively taking root in the speech of adolescents.

\section{Conclusions}

Analyzing the influence of slang on the vocabulary of a modern teenager, we highlighted both its positive and negative aspects.

The positive aspects of online communication.

1. Teenagers like to use Internet slang. They are happy when they write on the same slang. This liberates them, they can freely communicate on any topic. Thus, the guys cease to feel loneliness and do not remain face to face with their problems. Nowadays it is very important.

2. Slang allows you to communicate quickly, which is very convenient in our time. Usually in chat rooms and on VK, correspondence is conducted with several people at once, and therefore the speed of writing is also important here.

3. Such language makes communication simple, accessible and fun.

The negative sides of online communication.

1. Because of the interest in Internet slang, teenagers write with errors that distort spoken and written speech not only in forums, but also in everyday life (in particular, in notebooks on the Russian language).

2. Incorrect speech is heard not only on the Internet, but also from television screens, on the radio, i.e. in everyday life.

3. In the speech of adolescents appears a lot of foreign words used without translation.

4. Internet communication contains many obscene phrases that lead to clogging of the language.

\section{Acknowledgements}

The work is performed according to the Russian Government Program of Competitive Growth of Kazan Federal University. 


\section{References}

But, M.A. (2011). Reflection of the development of information and communication technologies in the lexical system of the English language. Young scientist, 2(6(29)), 10-12. https://moluch.ru/archive/146/41110/

Collins, F. (2017). dissertation the Affect and Effect of Internet Memes: Assessing Perceptions and Influence of Online User-Generated Political Discourse as Media. H. Huntington Department of Journalism and Media Communication, p.39. https://mountainscholar.org/bitstream/handle/10217/183936/Huntington_colostate_0053A _14303.pdf

Evans, V. (2017). The emoji code. Michael Omara Books, p. 18. https://www.amazon.com/EmojiCode-Linguistics-Behind-Scaredy/dp/1250129060

Golovanova, D.S. (2012). The impact of Internet slang on speech culture.Young scientist, 3(23), 13. https://moluch.ru/young/archive/23/1409/

Gratch, L.M. (2017). Creating memes, Sweding movies and other digital performances. Lexington books, https://books.google.ru/books?id=kFoxDwAAQBAJ\&pg=PA5\&lpg=PA5\&dq=richard+da wkins+meme+books+online\&sour

Haarmn, H. (1986). Language in ethnicity: a view of basic ecological relations. Mouton de Gruyter, 257-267. https://books.google.ru/books?id=idAfAAAAQBAJ\&pg=PA278\&lpg=PA278\&dq=harald +haarmann+7+environmental+vari

Kovalenko, O.V. (2010). Language and technology:the impact of computer terminology on spoken English language. Young scientist, 6(17), 329-334 https://moluch.ru/archive/17/17/1676/

Levikova, S.I. (2004). Youth slang as a perspective method of verbalization. Genesis and language, 167-173. http://www.philology.ru/linguistics2/levikova-

Savitskaya, T.E. (2013). Internet memes a phenomenon of mass culture. Culture in modern world, Electronic resource, http://infoculture.rsl.ru/NIKLib/althome/news/KVM_archive/articles/2013/03/2013/03/201

Sibthorpe, G. (2014). The effects of digital communication on everyday speech. Parall.Ax blog. https://parall.ax/blog/view/3106/the-effects-of-digital-communication-on-everyday-speech 